\title{
Basalt weathering rates on Earth and the duration of liquid water on the plains of Gusev Crater, Mars
}

\author{
E.M. Hausrath ${ }^{1,2 *}$ \\ A.K. Navarre-Sitchler ${ }^{2}$ \\ P.B. Sak ${ }^{3}$ \\ C. Steefel ${ }^{4}$ \\ S.L. Brantley ${ }^{2}$ \\ ${ }^{1}$ Department of Geosciences, Penn State University, University Park, PA 16802 \\ 2 Johnson Space Center, Houston, TX 77058 \\ ${ }^{3}$ Department of Geology, Dickinson College, Carlisle, PA 17013 \\ ${ }^{4}$ Earth Sciences Division, Lawrence Berkeley National Laboratory, Berkeley, CA 94720 \\ *Corresponding author: Elisabeth.M.Hausrath@ nasa.gov
}

\begin{abstract}
Where Martian rocks have been exposed to liquid water, chemistry versus depth profiles could elucidate both Martian climate history and potential for life. The persistence of primary minerals in weathered profiles constrains the exposure time to liquid water: on Earth, mineral persistence times range from $\sim 10 \mathrm{ka}$ (olivine) to $\sim 250 \mathrm{ka}$ (glass) to $\sim 1 \mathrm{Ma}$ (pyroxene) to $\sim 5 \mathrm{Ma}$ (plagioclase). Such persistence times suggest mineral persistence minima on Mars. However, Martian solutions may have been more acidic than on Earth. Relative mineral weathering rates observed for basalt in Svalbard (Norway) and Costa Rica demonstrate that laboratory $\mathrm{pH}$ trends can be used to estimate exposure to liquid water both qualitatively (mineral absence or presence) and quantitatively (using reactive transport models). Qualitatively, if the Martian solution $\mathrm{pH}>$ $\sim 2$, glass should persist longer than olivine; therefore, persistence of glass may be a $\mathrm{pH}$ indicator. With evidence for the $\mathrm{pH}$ of weathering, the reactive transport code CrunchFlow can quantitatively calculate the minimum duration of exposure to liquid water consistent with a chemical profile. For the profile measured on the surface of Humphrey in Gusev Crater, the minimum exposure time is $22 \mathrm{ka}$. alteration accompanied by ongoir._-rface erosion. More of these depth profiles should be measured to illuminate the weathering history of Mars.
\end{abstract}

Keywords: Mars, basalt, weathering, reactive transport modeling, rind, pH INTRODUCTION

To understand whether life could have existed or still exists on Mars, we need to be able to use data such as that from the Mars Exploration Rovers (Herkenhoff et al., 2004; Squyres et al., 2004; Haskin et al., 2005), the Mars Express satellite (Poulet et al., 2005; Bibring et al., 2006), and meteorites (Gooding et al., 1991; Treiman et al., 1993; Treiman, 2005) to constrain the duration and distribution of liquid water. Such data document the presence of primary silicates such as olivine (Hoefen et al., 2003), pyroxene (Mustard et al., 1997), plagioclase (Bandfield, 2002) and glass (Bandfield et al., 2000; Ruff et al., 2006) that may have weathered to secondary minerals (Christensen et al., 2000; Poulet et al., 2005; Bibring et al., 2006). Here, we 
use both qualitative (mineral absence or presence) and quantitative (reactive transport modeling) approaches to interpret basalt weathering on Earth and on Mars.

\section{Mineral Persistence}

Minerals persist for different lengths of time in terrestrial weathering environments (Goldich, 1938). To quantify how long a mineral persists before it is solubilized (mineral persistence time) on Earth, we examined the lengths of time that minerals persist in dated soils and chronosequences (Fig. 1; Appendix 1). We observed that persistence times varied from $\sim 10 \mathrm{ka}$ (olivine) to $\sim 250 \mathrm{ka}$ (glass) to $\sim 1 \mathrm{Ma}$ (pyroxene) to $\sim 5 \mathrm{Ma}$ (plagioclase), consistent with Goldich. The relative order of these mineral persistences is largely consistent with dissolution experiments (Fig. 2) at $\mathrm{pH} \sim 5.5-7$. Mineral composition affects the observed persistence times: for example, relative persistence times for plagioclase in Figure 1 which includes all compositions are longer than in Figure 2, where only bytownite is represented.

Given the higher water fluxes, erosion rates, and tectonic activity on Earth, mineral persistence times depicted in Figure 1 are probably minimum estimates of Martian mineral persistence. However, such extrapolations depend upon the $\mathrm{pH}$ of weathering (Fig. 2) and such $\mathrm{pH}$ is poorly constrained on Mars: weathering $\mathrm{pH}$ may have been very acidic (Elwood Madden et al., 2004; Klingelhofer et al., 2004; Tosca et al., 2004; Hurowitz et al., 2006) or close to neutral (Poulet et al., 2005; Bibring et al., 2006). The pH of a weathering solution strongly affects relative mineral persistences (Fig. 2). For example, at extremely low $\mathrm{pH}$, laboratory experiments (Fig. 2) predict dissolution rates of basalt glass $>$ olivine. For $2<\mathrm{pH}<8$, however, olivine dissolves more quickly than basalt glass.

Persistence times of diopside and bytownite should also be lower than glass at low $\mathrm{pH}$ but roughly the same at $\mathrm{pH} \approx 4-6$. Plagioclase dissolution rates increase with increasing $\mathrm{Ca}$ content (Blum and Stillings, 1995), but reported rates for pyroxene do not vary strongly with composition.

To determine if a diagram such as Figure 2 is useful to predict Martian basalt weathering, we first compare its predictions to basalt weathering in Costa Rica and Svalbard. In Costa Rica pyroxene alters before plagioclase, which is consistent with the measured $\mathrm{pH}$ of porewaters $(\sim 4.7)$ (Fig. 2). On weathered surfaces in Svalbard, Na-containing glass is weathered to depths of $\sim 250 \mu \mathrm{m}$ (Figs. 3, 4). Olivine phenocrysts intersecting the surface do not protrude significantly nor show embayment (Fig. 3b). Smoothing of $\sim 20-40 \mu \mathrm{m}$ of the phenocryst roughness at the rock surface yields a minimum estimate of the weathering advance distance due to free-face dissolution. The observation that glass is dissolving deeper (more quickly) than olivine is consistent with the measured porefluid $\mathrm{pH}$ range for Svalbard ( 7-9) (Fig. 2).

Since relative mineral weathering in Costa Rica and Svalbard follows $\mathrm{pH}$ trends documented by dissolution experiments, extrapolation of these trends to the Martian surface should reveal $\mathrm{pH}$ conditions of Martian weathering. Mineral compositions on Mars range from intermediate to ferroan olivine (McSween et al., 2006) and intermediate to calcic plagioclase (Bandfield, 2002; McSween et al., 2004). Both high and low Ca pyroxenes have been detected (Mustard et al., 1997; Hamilton et al., 2003; Bibring et al., 2005; McSween et al., 2006). Glass of a basaltic andesite composition, documented in a Martian meteorite (Greshake et al., 2004), would dissolve only slightly more slowly than the basalt glass dissolution line on Figure 2 . The diopside dissolution line represents a good estimate for dissolution of Martian pyroxenes. The plagioclase dissolution rate may be up to one order of magnitude lower than the plotted line for 
bytownite. At the low $\mathrm{pH}$ values suggested for Mars, relative weathering of glass and olivine may yield constraints on $\mathrm{pH}$. For example, Mangold et al. (2007) propose that relatively unaltered olivine may be found with altered glass in the Nili Fossae region of Mars. Such dissolution of glass without alteration of olivine is consistent (Fig. 2) with either very low or high $\mathrm{pH}$

\section{Reactive Transport Modeling}

Where concentration-depth data is available such as on the rock Humphrey in Gusev Crater on Mars (Gellert et al., 2006), it is possible to calculate weathering duration using reactive transport codes. We used CrunchFlow (Maher et al., 2006) to forward model weathering rinds from Costa Rica, Svalbard, and Humphrey (Fig. 4) in one dimension using laboratory rates and diffusivities (Appendix 1). For the Costa Rica basalt, dissolution of plagioclase and pyroxene and precipitation of $\mathrm{Fe}$ and $\mathrm{Al}$ oxides in the reaction front were modeled (Fig. 4a). The weathering rock was modeled as $66 \%$ plagioclase $+26 \%$ pyroxene $+2.6 \%$ quartz $+1.8 \%$ alkali feldspar $+1 \%$ magnetite $+1.5 \%$ ilmenite $+1 \%$ porosity. Secondary minerals allowed to precipitate include kaolinite, $\mathrm{Fe}(\mathrm{OH})_{3}$, gibbsite, and siderite. CrunchFlow was similarly used to fit dissolution of Na-containing glass in Svalbard where the weathering rock was modeled as $25 \%$ glass $+73 \%$ inert mineral $+2 \%$ porosity because only glass was observed to dissolve (Appendix 1). No secondary minerals were included since few were observed. This implicitly assumes that while olivine dissolves by free-face dissolution at the surface, its dissolution rate within the rock is negligible relative to glass. The model fit to the glass dissolution is consistent with an inferred surface retreat of $\sim 0.4 \mathrm{~mm}$ (Fig. $4 \mathrm{~b}$ ), consistent with petrographic observations of spalling (Appendix 1).

The Alpha Particle X-ray Spectrometers on the Mars Exploration Rovers have measured chemistry with depth in drilled holes for many rocks (Gellert et al., 2006). When profiles are normalized to $\mathrm{Ti}$, negative values of the dimensionless mass-element-transfer coefficient $\tau_{\mathrm{Ti}, \mathrm{j}}$ (Appendix 1) for elements such as $\mathrm{Mg}, \mathrm{Fe}, \mathrm{Ca}$ and $\mathrm{P}$ are observed. $\mathrm{Mg}$ and $\mathrm{Fe}$ loss from the inferred weathering rind on Mars rock Humphrey is consistent with olivine loss (Hurowitz et al., 2006). Humphrey is inferred to contain plagioclase, pyroxene, and Fo52 with up to $10 \%$ highsilica glass (Ruff et al., 2006). The weathering rind on Humphrey (McSween et al., 2004; Gellert et al., 2006) (Fig. 3) is modeled here because abrasion reached unaltered parent (Gellert et al., 2006), and forward modeling relies upon knowledge of parent material.

All Fe and $\mathrm{Mg}$ loss was attributed to olivine dissolution, similar to our earlier assumption of $\mathrm{Na}$ loss due to glass dissolution for Svalbard. Fe and $\mathrm{Mg}$ (McSween et al., 2004) were assigned to Fo84 and Fo25, the two probable end members of zoning in Humphrey (McSween et al., 2006). The olivine is probably zoned; this simplification facilitates modeling. The assumption of Fo84 (14\%) and Fo25(11\%) results in a rock that is $25 \%$ olivine (McSween et al., 2004; McSween et al., 2006). Following our approach to Svalbard, the rest of the rock (72\%) is assumed to be inert.

The shortest time that allowed a fit to the reaction front was $22 \mathrm{ka}$ with a modeled weathering advance rate of $10^{-8} \mathrm{~m} \mathrm{yr}^{-1}$. In contrast to Svalbard, the front was fit without surface retreat. However, Mars experiences physical erosion at rates of $0.04 \times 10^{-9}$ (Golombek and Bridges, 2000) to $3 \times 10^{-3} \mathrm{~m} \mathrm{yr}^{-1}$ (Sagan, 1973). Since the chemical weathering advance rate is within the range of physical erosion rates, the profile could represent steady-state thickness 
(weathering rate $=$ erosion rate). In any case, it is likely that erosion removed some of the surface of Humphrey, implying that the calculated $22 \mathrm{ka}$ is a minimum weathering duration

This $22 \mathrm{ka}$ weathering duration is within a factor of $\sim 10$ of the olivine persistence times in terrestrial and laboratory environments (Fig. 1), as well as the time estimates by Stopar et al. (2006) for similar conditions on Mars (1.6-1.9 ka. Adirondack rocks in Gusev Crater, suggesting that ${ }_{1}$,resence of water in this location was extremely brief, or that physical weathering is occurring at close to the same rates as chemical weathering. The $22 \mathrm{ka}$ time of weathering may also represent summation of sporadic wet time periods interspersed with much longer dry periods as inferred for meteorites (e.g Treiman et al., 1993). Such shortlived and episodic alteration may be more consistent with alteration such as that resulting from impacts, rather than more long-lived aqueous alteration such as surface oceans. The weathering duration inferred for diffusion-dominated transport used in our model is also consistent with low water-rock ratios inferred for Adirondack rocks in Gusev crater such as acid-sulfate weathering or thin films of water under snow or frost (Hurowitz et al., 2006).

The hole on Humphrey is one of the shallowest drilled by the Spirit Rover (Arvidson et al, 2006). A number of studies (Ming et al., 2006; Morris et al., 2006) have found that while the Adirondack rocks (which include Humphrey), are minimally weathered, weathering in Columbia Hills was much more intensive. Satellite data document phyllosilicates (Poulet et al., 2005; Bibring et al., 2006), hematite and sulfate (Christensen et al., 2000; Bandfield, 2002; Gendrin et al., 2005). Depth profiles in such areas might yield more information regarding the aqueous history of Mars.

\section{CONCLUSIONS}

Terrestrial mineral persistence data suggest minimum persistence times for olivine (10ka), glass (250 ka), pyroxene ( 1Ma), plagioclase ( $\sim \mathrm{Ma})$ on Mars. These relative mineral weathering rates and relative mineral weathering rates in Svalbard (Norway) and Costa Rica are consistent with $\mathrm{pH}$ values of weathering solutions. This suggests that relative persistences on Mars (particularly olivine and glass) may be used to constrain the $\mathrm{pH}$ of the weathering fluid. The successful use of reactive transport modeling to match reaction fronts in basalts on Earth lends confidence to the utility of using reactive transport modeling for Mars. The CrunchFlow fit of the weathering rind on Humphrey requires $22 \mathrm{ka}$ of weathering, and could represent steadystate thickness (weathering rate $=$ erosion rate). In any case, the $22 \mathrm{ka}$ is a minimum time of exposure to liquid water for this Mars rock due to the presence of physical weathering, and suggests short-term and episodic aqueous alteration in this location. This interpretation of weathering profiles on Mars suggests the type of depth profiles that could be collected to further interpret the aqueous history of Mars.

\section{ACKNOWLEDGMENTS}

We thank J. Moore, J. Bandstra, M. Angelone, J. Cantolina, D. Eggler, J. Mustard, AMASE, WUN, BRIE (NSF IGERT grant DGE-9972759), PSARC, NASA NNG05GN72G, an NAI Research Fellowship, and NSF Graduate Research Fellowship (EMH). We appreciate thoughtful reviews by J. Bandfield, T. Lyons, H. McSween, and J. Taylor. This work was supported in part by the Director, Office of Science, Office of Basic Energy Sciences, Division of Chemical Sciences, Geosciences, and Biosciences of the U.S. Department of Energy under Contract No. DE-AC02-05CH11231 to Lawrence Berkeley National Laboratory. 


\section{REFERENCES CITED}

Arvidson, R.E. and 62 others, 2006, Overview of the Spirit Mars Exploration Rover Mission to Gusev Crater: Landing site to Backstay Rock in the Columbia Hills: Journal of Geophysical Research, v. 111, p. doi:10.1029/2005JE002499.

Bandfield, J.L., 2002, Global mineral distribution on Mars: Journal of Geophysical Research, v. 107, p. 5042, doi: 10.1029/2001JE001510,

Bandfield, J.L., Hamilton, V.E., and Christensen, P.R., 2000, A Global View of Martian Surface Compositions from MGS-TES: Science, v. 287, p. 1626-1630, doi: 10.1126/science.287.5458.1626.

Bandstra J.Z., and Brantley S.L. Data Fitting Techniques with Applications to Mineral Dissolution Kinetics, in Kinetics of Water-Rock Interaction, S. L. Brantley, J. D. Kubicki and A. F. White (eds.), Springer, New York. In press.

Bibring, J.-P., Langevin, Y., Gendrin, A., Gondet, B., Poulet, F., Berthe, M., Soufflot, A., Arvidson, R., Mangold, N., Mustard, J., Drossart, P., the OMEGA team, 2005, Surface Diversity as Revealed by the OMEGA/Mars Express Observations: Science, v. 307, p. 1576-1581, doi: 10.1126/science.1108806.

Bibring, J.P., Langevin, Y., Mustard, J.F., Poulet, F., Arvidson, R., Gendrin, A., Gondet, B., Mangold, N., Pinet, P., Forget, F., the OMEGA team, 2006, Global Mineralogical and Aqueous Mars History derived from OMEGA/Mars Express Data: Science, v. 312, p. 400404, doi: 10.1126/science. 1122659.

Blum, A.E., and Stillings, L.L., 1995, Feldspar dissolution kinetics, in White, A.F., and Brantley, S.L., eds., Chemical Weathering Rates of Silicate Minerals, Volume 31: Reviews in Mineralogy: Washington, D.C., Mineralogical Society of America, p. 291-351.

Christensen, P.R., Bandfield, J.L., Clark, R.N., Edgett, K.S., Hamilton, V.E., Hoefen, T.M., Kieffer, H.H., Kuzmin, R.O., Lane, M.D., Malin, M.C., Morris, R.V., Pearl, J.C., Pearson, R., Roush, T.L., Ruff, S.W., and Smith, M.D., 2000, Detection of crystalline hematite mineralization on Mars by the Thermal Emission Spectrometer: Evidence for near-surface water: Journal of Geophysical Research, v. 105, p. 9623-9642, doi: 10.1029/1999JE001093.

Elwood Madden, M.E., Bodnar, R.J., and Rimstidt, J.D., 2004, Jarosite as an indicator of waterlimited chemical weathering on Mars: Nature, v. 431, p. 821-823, doi: 10.1038/nature02971.

Gellert, R., Rieder, R., Bruckner, J., Clark, B.C., Dreibus, G., Klingelhofer, G., Lugmair, G., Ming, D.W., Wanke, H., Yen, A., Zipfel, J., and Squyres, S.W., 2006, Alpha Particle X-Ray Spectrometer (APXS): Results from Gusev crater and calibration report: Journal of Geophysical Research, v. 111, p. doi:10.1029/2005JE002555.

Gendrin, A., Mangold, N., Bibring, J-P., Langevin, Y., Gondet, B., Poulet, F., Bonello, G., Quantin, C., Mustard, J., Arvidson, R., LeMouélic, S. 2005, Sulfates in Martian Layered Terrains: The OMEGA/Mars Express View: Science, v. 307, p. 1587-1591.

Goldich, S., 1938, A study of rock weathering: The Journal of Geology, v. 46, p. 17-58.

Golombek, M., and Bridges, J.C., 2000, Erosion rates on Mars and implications for climate change: Constraints from the Pathfinder landing site: Journal of Geophysical Research, v. 105, p. 1841-1854, doi: 10.1029/1999JE001043.

Gooding, J.L., Wentworth, S.J., and Zolensky, M.E., 1991, Aqueous alteration of the Nakhla meteorites: Meteoritics, v. 26, p. 135-143. 
Greshake, A., Fritz, J., and Stoffler, D., 2004, Petrology and shock metamorphism of the olivinephyric shergottite Yamato 980459: Evidence for a two-stage cooling and a single-stage ejection history: Geochimica et Cosmochimica Acta, v. 68, p. 2359-2377, doi: 10.1016/j.gca.2003.11.022.

Hamilton, V., Christensen, P., McSween, H., and Bandfield, J., 2003, Searching for the source regions of martian meteorites using MGS TES: Integrating martian meteorites into the global distribution of igneous materials on Mars: Meteoritics \& Planetary Science, v. 38, p. 871-885.

Haskin, L.A., and 29 others 2005, Water alteration of rocks and soils on Mars at the Spirit rover site in Gusev crater: Nature, v. 436, p. 66-69, doi: 10.1038/nature03640.

Herkenhoff, K.E., and 32 others, 2004, Evidence from Opportunity's Microscopic Imager for Water on Meridiani Planum: Science, v. 306, p. 1727-1730, doi: 10.1126/science.1105286.

Hoefen, T.M., Clark, R.N., Bandfield, J.L., Smith, M.D., Pearl, J.C., and Christensen, P.R., 2003, Discovery of olivine in the Nili Fossae region of Mars: Science, v. 302, p. 627-630, doi: 10.1126/science.1089647.

Hurowitz, J.A., McLennan, S., Tosca, N., Arvidson, R., Michalski, J.R., Ming, D.W., Schroder, C., and Squyres, S.W., 2006, In situ and experimental evidence for acidic weathering of rocks and soils on Mars: Journal of Geophysical Research, v. 111., E02S19, doi:10.1029/2005JE002515.

Klingelhofer, G., Morris, R.V., Bernhardt, B., Schroder, C., Rodionov, D.S., de Souza, P.A., Jr., Yen, A., Gellert, R., Evlanov, E.N., Zubkov, B., Foh, J., Bonnes, U., Kankeleit, E., Gutlich, P., Ming, D.W., Renz, F., Wdowiak, T., Squyres, S.W., and Arvidson, R.E., 2004, Jarosite and Hematite at Meridiani Planum from Opportunity's Mossbauer Spectrometer: Science, v. 306, p. 1740-1745, doi: 10.1126/science.1104653.

Maher, K., Steefel, C.I., DePaolo, D.J., and Viani, B.E., 2006, The mineral dissolution rate conundrum: Insights from reactive transport modeling of $U$ isotopes and pore fluid chemistry in marine sediments: Geochimica et Cosmochimica Acta, v. 70, p. 337-363, doi: 10.1016/j.gca.2005.09.001.

Mangold, N., Poulet, F. Mustard, J.F., Bibring, J-P., Gondet, B., Langevin, Y., Ansan, V., Masson, Ph., Fassett, C., Head III, J.W., Hoffmann, H., Neukum, G. 2007, Mineralogy of the Nili Fossae region with OMEGA/MEx data:2. Aqueous alteration of the crust: Journal of Geophysical Research, p. doi:10.1029/2006JE002835.

McSween, H.Y., and 34 others., 2004, Basaltic rocks analyzed by the Spirit rover in Gusev Crater: Science, v. 305, p. 842-845, doi: 10.1126/science.3050842.

McSween, H.Y., and 41 others, 2006, Characterization and petrologic interpretation of olivinerich basalts at Gusev Crater, Mars,: Journal of Geophysical Research, v. 111, p. doi:10.1029/2005JE002477.

Ming, D.W., Mittlefehldt, D.W., Morris, R.V., Golden, D.C., Gellert, R., Yen, A., Clark, B.C., Squyres, S.W., Farrand, W.H., Ruff, S.W., Arvidson, R.E., Klingelhöfer, G., McSween, H.Y., Rodionov, D.S., Schröder, C., de Souza, P.A.. and Wang, A. 2006, Geochemical and mineralogical indicators for aqueous processes in the Columbia Hills of Gusev crater, Mars: Journal of Geophysical Research, v. 111, p. doi:10.1029/2005JE002560.

Morris, R.V., Klingelhöfer, G., Schröder, C., Rodionov, D.S., Yen, A., Ming, D.W., Jr., P.A.d.S., Fleischer, I., Wdowiak, T., Gellert, R., Bernhardt, B., Evlanov, E.N., Zubkov, B., Foh, J., Bonnes, U., Kankeleit, E., Gütlich, P., Renz, F., Squyres, S.W., and Arvidson, R.E., 2006, Mössbauer mineralogy of rock, soil, and dust at Gusev crater, Mars: Spirit's journey through 
weakly altered olivine basalt on the plains and pervasively altered basalt in the Columbia Hills: Journal of Geophysical Research, v. 111, p. doi:10.1029/2005JE002584.

Mustard, J.F., Murchie, S., Erard, S., and Sunshine, J., 1997, In situ compositions of Martian volcanics: Implications for the mantle: Journal of Geophysical Research, v. 102, p. 2560525615, doi: 10.1029/97JE02354.

Poulet, F., Bibring, J.-P., Mustard, J.F., Gendrin, A., Mangold, N., Langevin, Y., Arvidson, R.E., Gondet, B., and Gomez, C.,, 2005, Phyllosilicates on Mars and implications for early martian climate: Nature, v. 438, p. 623-627, doi: 10.1038/nature04274.

Ruff, S.W., Christensen, P.R., Blaney, D.L., Farrand, W.H., Johnson, J.R., Michalski, J.R., Moersch, J.E., Wright, S.P., and Squyres, S.W., 2006, The rocks of Gusev Crater as viewed by the Mini-TES instrument: Journal of Geophysical Research, v. 111, p. doi:10.1029/2006JE002747.

Sagan, C., 1973, Sandstorms and eolian erosion on Mars: Journal of Geophysical Research, v. 78, p. 4155-4161.

Sak, P.B., Fisher, D.M., Gardner, T.W., Murphy, K., and Brantley, S.L., 2004, Rates of weathering rind formation on Costa Rican basalt: Geochimica et Cosmochimica Acta, v. 68, p. 1453-1472, doi: 10.1016/j.gca.2003.09.007.

Squyres, S.W., Grotzinger, J.P., Arvidson, R.E., Bell, J.F., III, Calvin, W., Christensen, P.R., Clark, B.C., Crisp, J.A., Farrand, W.H., Herkenhoff, K.E., Johnson, J.R., Klingelhofer, G., Knoll, A.H., McLennan, S.M., McSween, H.Y., Jr., Morris, R.V., Rice, J.W., Jr., Rieder, R., and Soderblom, L.A., 2004, In situ evidence for an ancient aqueous environment at Meridiani Planum, Mars: Science, v. 306, p. 1709-1714, doi: 10.1126/science.1104559.

Stopar, J. S., G. J. Taylor, V. E. Hamilton, L. Browning (2006) Kinetic Model of Olivine Dissolution and Extent of Aqueous Alteration on Mars. Geochem. Cosmochim. Acta 70, 6136-6152.

Tosca, N.J., McLennan, S., Lindsley, D.H., and Schoonen, M.A.A., 2004, Acid-sulfate weathering of synthetic Martian basalt: The acid fog model revisited: Journal of Geophysical Research, v. 109, p. doi:10.1029/2003JE002218.

Treiman, A.H., 2005, The nakhlite meteorites: augite-rich igneous rocks from Mars: Chemie der Erde, v. 65, p. 203-270, doi: 10.1016/j.chemer.2005.01.004.

Treiman, A.H., Barrett, R.A., and Gooding, J.L., 1993, Preterrestrial alteration of the Lafayette (SNC) meteorite: Meteoritics, v. 28, p. 86-97. 


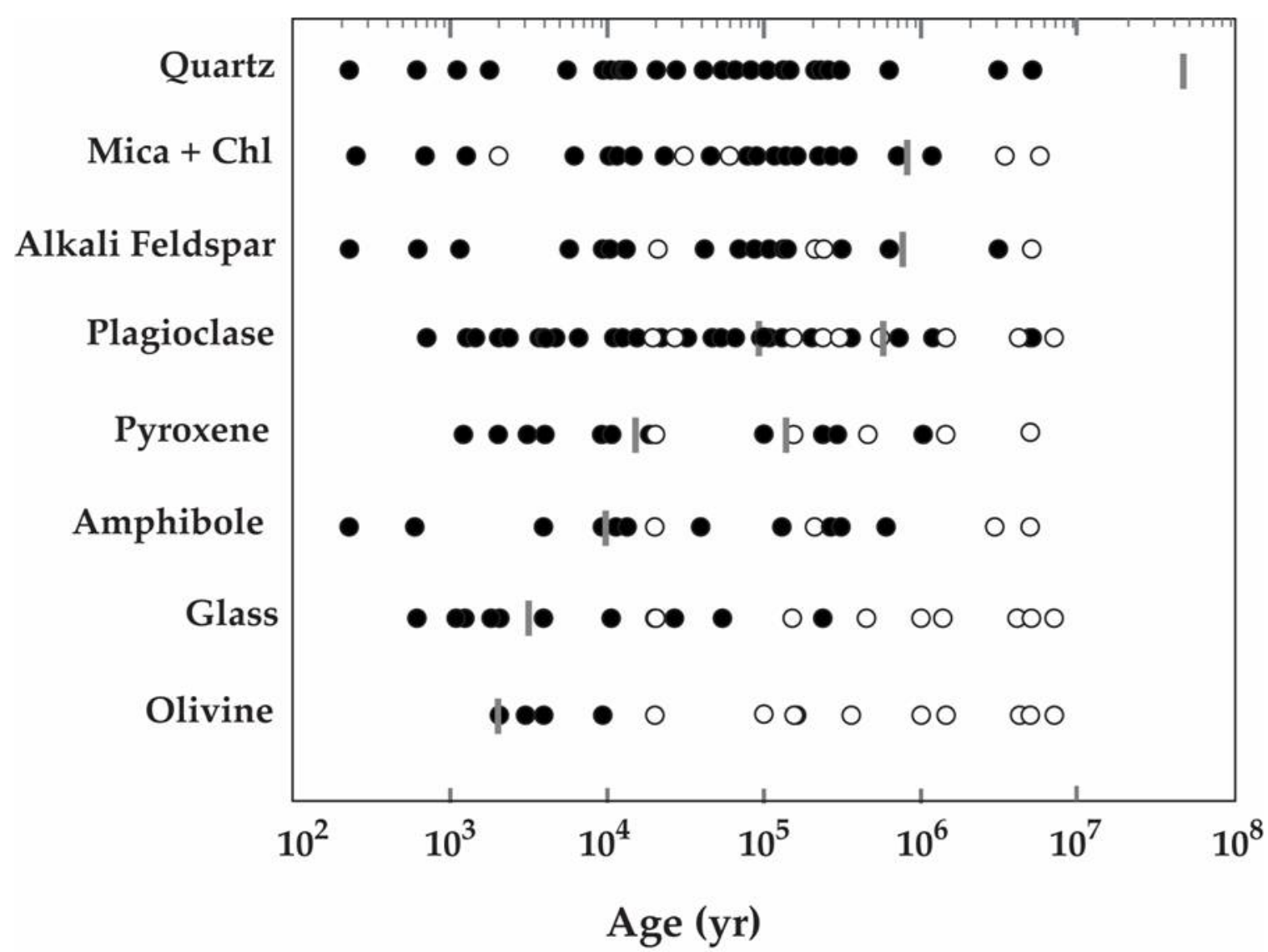

Figure 1. Mineral persistence times defined by $\geq 2 \%$ abundance (closed symbols) of silicates in A and B horizons of modern, dated soils and weathering rinds versus soil age. Open symbols $=$ phase is no longer present within a chronosequence. Gray bars = lifetimes of $1 \mathrm{~mm}$ silicate spheres calculated from laboratory rate laws at $\mathrm{pH}=5$; pairs of gray bars $=$ end member compositions. Data compilation described in Appendix 1. 


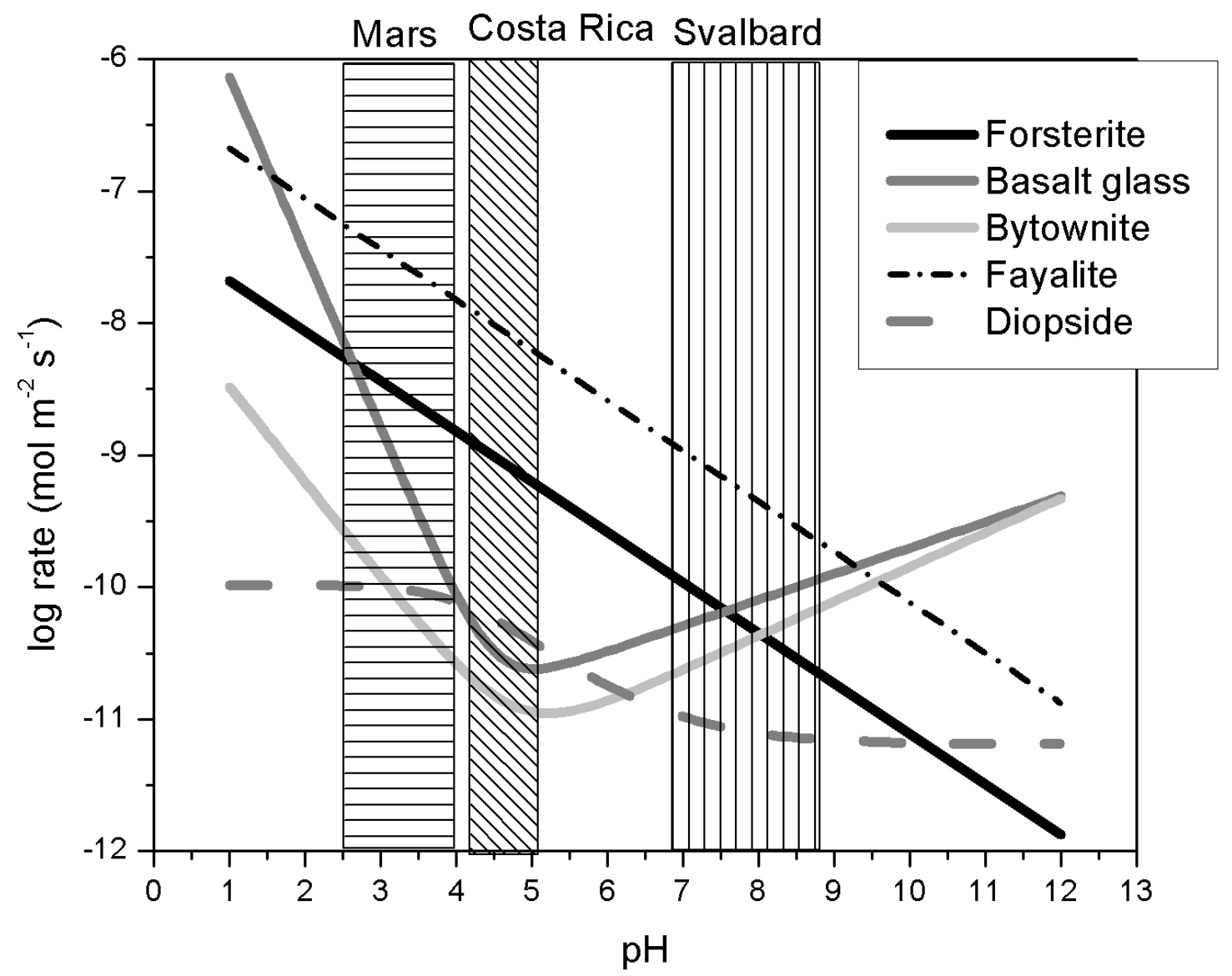

Figure 2. Log dissolution rates of silicates versus $\mathrm{pH}$. Forsterite, basalt glass, and diopside rates from Bandstra and Brantley (in press). Bytownite is estimated from albite, and fayalite from forsterite (Bandstra and Brantley, in press) (Appendix 1). Ranges labeled Svalbard, Costa Rica and Mars represent estimated $\mathrm{pH}$ from soil measurements (Svalbard and Costa Rica) or the stability field of jarosite (Mars; Elwood Madden et al., 2004). 


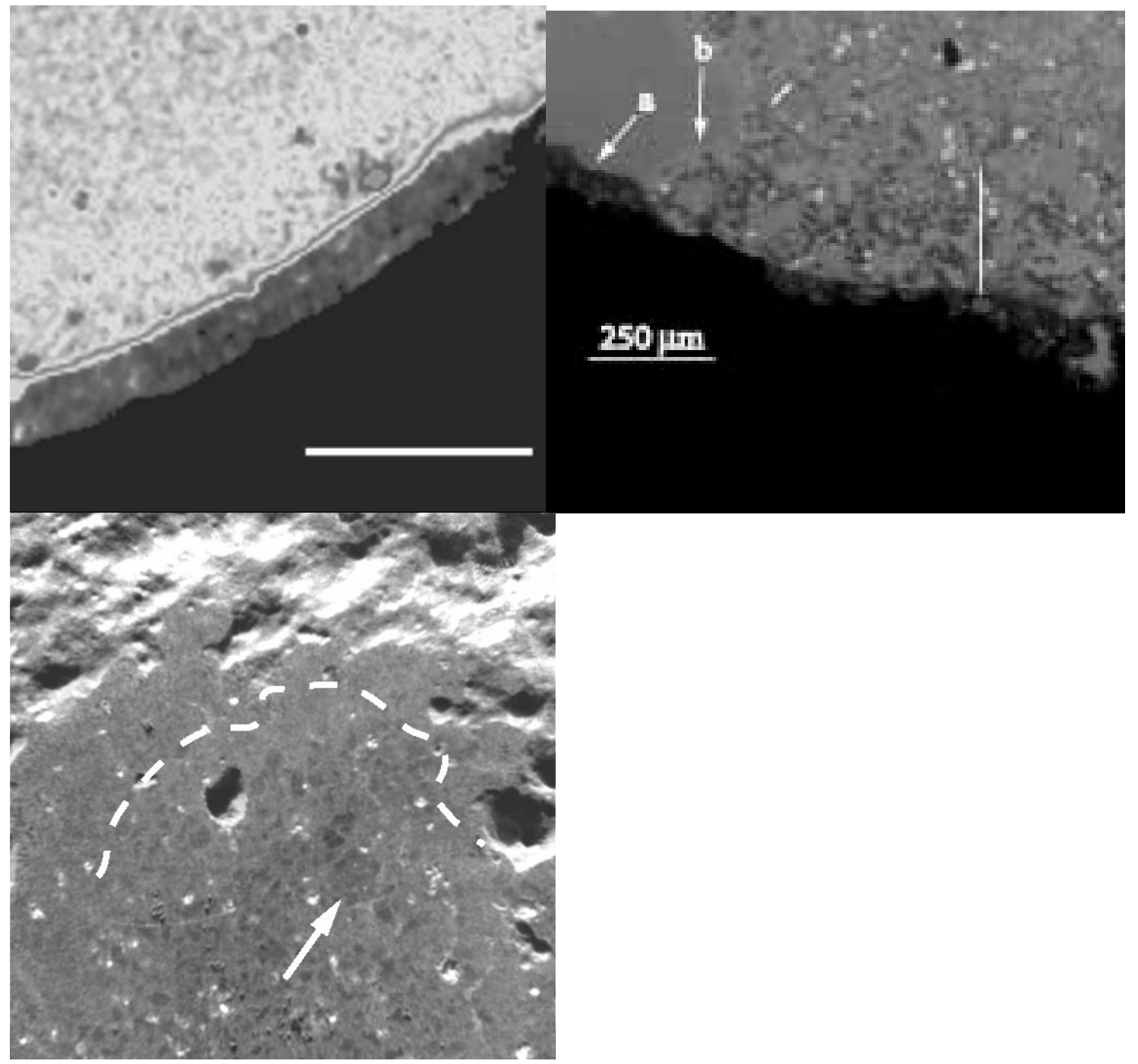

Figure 3. Weathering rinds on basalt samples from a) Costa Rica b) Svalbard and c) Mars. Figure 3a is a computed tomography image of a $1.2 \mathrm{~cm}$-thick weathering rind developed over $35 \mathrm{ka}$ on a basalt clast in Costa Rica (Sak et al., 2004). Unweathered core (gray) is rimmed with Fe and Al oxides of the weathering rind (dark material). Weathering increases porosity (black areas). The large olivine grain imaged by back-scattered electron micrography in Figure 3b displays a smoothed outer surface (letter a) without a zoned rim (letter b) (see text). Black areas present to $\sim 250 \mu \mathrm{m}$ (white line) are pore space created by glass dissolution. The double headed arrow indicates an example of a mineral aggregate used to estimate surface area (Appendix 1). Figure $3 \mathrm{c}$ is a Microscopic Image of an inferred weathering rind (dashed white line (McSween et al., 2004)) on abraded rock Humphrey on Mars.

(http://marsrovers.jpl.nasa.gov/gallery/all/spirit_p060.html). The arrow indicates an inferred olivine grain (McSween et al. (2006)). Figure $3 \mathrm{c}$ is $\sim 2 \mathrm{~cm}$ across. 

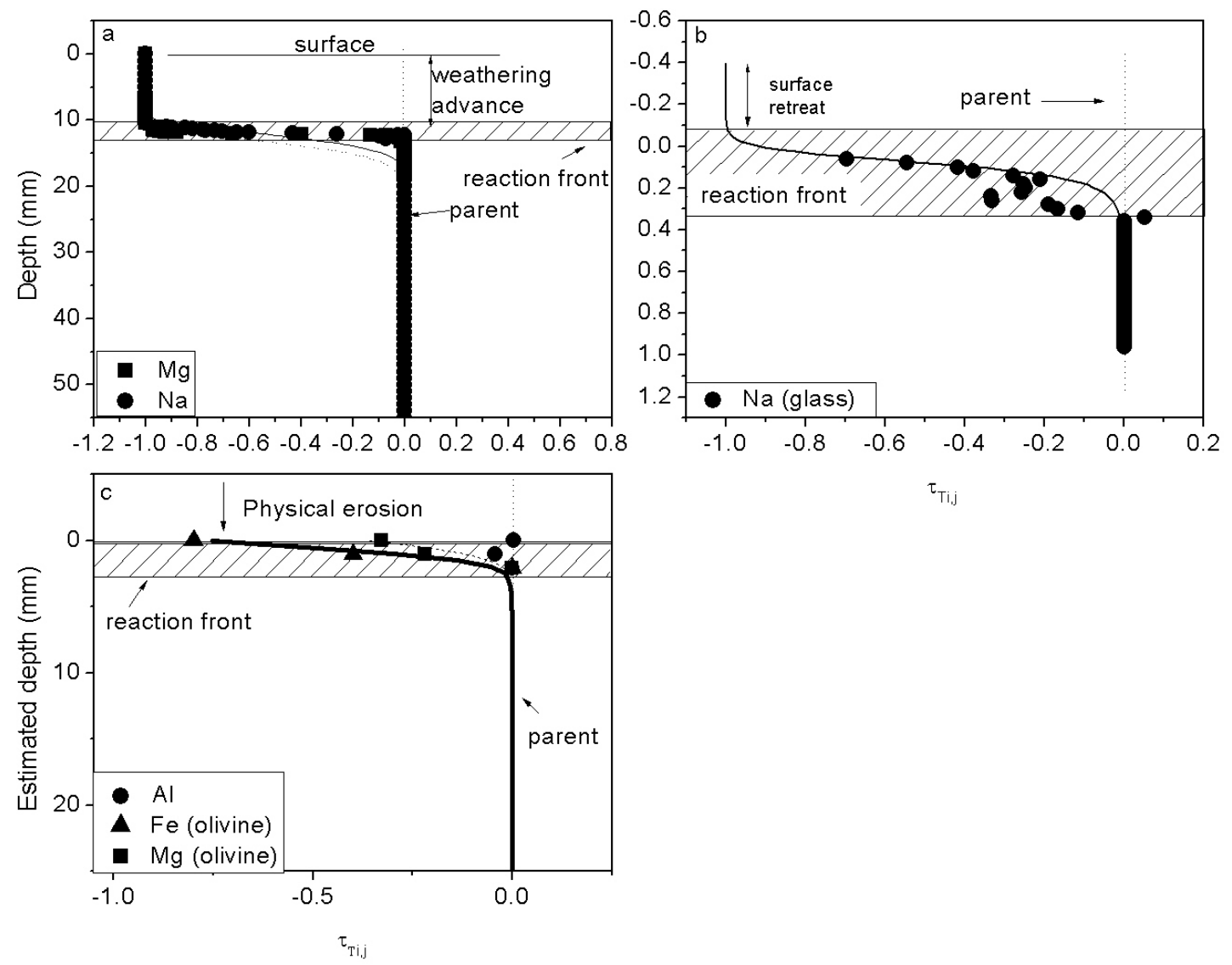

Figure 4. Plots of the dimensionless element-mass-transfer coefficient $\tau_{\mathrm{T} i \mathrm{j}}(=0$ for average parent, $=-1$ for $100 \%$ depletion) versus depth for weathered basalt from a) Costa Rica b) Svalbard, and c) Mars (Humphrey; Gellert et al., 2006). Profiles are normalized to Ti and except for c) represent the average of 9 or more profiles. Data symbols shown with CrunchFlow model output lines. Data in Figures 4a and 4b are smoothed with a 3-point and 5-point moving average respectively, and parent materials represent average compositions. In Figure $4 \mathrm{a} \mathrm{Na}$ is in plagioclase, and $\mathrm{Mg}$ in pyroxene, and parent and rind analyses are extended for effect. In Figure $4 \mathrm{~b} \mathrm{Na}$ is in glass. In Figure $4 \mathrm{c}, \mathrm{Mg}$ and $\mathrm{Fe}$ are in olivine. The Mars profile was first corrected for dust (Appendix 1). The weathering advance distance for the Costa Rican weathering rind is easily interpreted because, protected in deep soil, it has not eroded (Sak et al., 2004). In contrast, the $\sim 0.3 \mathrm{~mm}$ of glass dissolved on the basalt weathered in Svalbard is only an apparent distance because the surface has retreated due to erosion.

${ }^{1}$ GSA Data Repository item 2007xxx, supplementary methods and description, is available online at www.geosociety.org/pubs/ft2007.htm, or on request from editing@ geosociety.org or Documents Secretary, GSA, P.O. Box 9140, Boulder, CO 80301, USA. 